Doi: $10.24234 / \mathrm{se} .2020 .2 .2 .234$

\title{
MODERN ISSUES OF OVERCOMING STUTTERING IN SPEECH THERAPY
}

\author{
AUTHOR'S DATA: \\ Lilit Saratikyan, $\mathrm{PhD}$ in Education, Associated professor \\ Chair of Special Pedagogy and Psychology, Khachatur Abovyan Armenian State Pedagogical University, \\ Armenia \\ University lecturer \\ Contacts: saratikyanlilit41@aspu.am
}

\begin{abstract}
Despite the fact that the phenomenon of "stuttering" is quite a mature and comprehensively studied issue in speech therapy, still many ambiguous sides of this problem remain unresolved. Most modern researchers would agree that multiple factors, including those associated with linguistic, motor, sensory, and emotional processes, are likely involved in its development and preservation.

According to the conceptual analysis of the problem of speech therapy, the need for a comprehensive application of speech therapy methods in the process of overcoming stuttering, as well as the need to introduce them in social micro-macro environments, is indisputable. The "maps" outlining the guidelines and the action plan, which would support the effective implementation of the latter.

A qualitative framework was used in order to obtain the review and experience that specialists have had during their practices while working with stuttering person and his/her family.

Key words: stuttering, speech therapy, micro environment, macro environment, speech therapy intervention, family centered speech therapy.
\end{abstract}




\section{INTRODUCTION}

It is well known that stuttering, as an anthropological issue, is in focus of such scientific fields like psychology, medicine, special pedagogy, speech therapy, and pedagogy. This is evidenced by the theoretical facts in many social, psychological, pedagogical, medical and other sources that raise the health, psychological, pedagogical and social issues of stutterers. This kind of studies often reflect the fact that stuttering restricts a person's free socialization and affects his or her mental health (Lokhov \& Fesenko, 2000; Karpovan, 2003; Karpova, 2011).

The examined literature shows that stuttering is one of the most difficult speech disorders in human history, and still some issues related to overcoming this speech disorder and organization of speech therapy intervention and support have not yet been addressed properly. For example, theoretical research shows that there have been a lot of discussions in recent times about the need for verbal behavior management and family counseling for stutterers, but a complete functioning system has not yet been developed. The need for a comprehensive and in-depth study of these issues related with the requirements of modern speech therapy.

We believe that the latter can be the theoretical basis for developing new and effective approaches within the frame of family and speech therapy support.

\section{LITERATURE REVIEW}

From the analysis of the many existing views on speech therapy support, it has become clear that the issue under consideration is more relevant from the point of view of practical implementation of speech therapy assistance provided to stutterers and the creation of tools for its effective organization. In these processes, it is especially important to develop effective ways to organize speech therapy intervention and support for these individuals within the family, which, according to us, still need in-depth and extensive research. We think that in the process of overcoming stuttering those are issues that act as a serious challenge to modern speech therapy (Daniels \& Gabel, 2004; Yaruss \& Quesal, 2004; Huges, Gabel, Goberman \& Huges, 2011; Missulovin, 2012; Maniadaki, 2017).

Modern speech therapy supports the fact that more than ever, much attention has been paid to family involvement. This is evidenced by the fact that speech therapy support in many cases 
could be closely combined with family psychotherapy. It is a psychotherapeutic process organized with families through group work aimed at developing the ability of stutterers to participate in public speeches and development, as well as overcoming sociophobia (Drapkin, 2001).The view that it is not possible to regulate the speech of people with speech disorders, especially those who stutter during individual work, without the active participation of the social environment and the family, is shared by Harutyunyan (1993), Missulovin (2012), Hovhannisyan (2001), Nekrasova (2001), Paylozyan (2017) and others. According to this approach, the work of regulating the speech of these people can be overcome by the use of complex methods and speech set by a speech therapist in different social environments. In other words, it is about the regulated speech live and spontaneous use (Andronova, 1986; Paylozyan, 2010; 2017). At the same time, the success of this

complex work is based on the need for direct participation of families where person with speech disorder lives. The methods of family cooperation with speech therapists, development of tools, arming families with the necessary speech therapy tools, accompanying the stuttering process according to speech therapy guidelines are important factors in the process of treatment (Belyakova \& Dyakova, 2001).

From this point of view, the problem under study is certainly very relevant according to Daniles \& Gabel (2004) and Maniadaki (2017) that still requires very comprehensive solutions.

Based on the all mentioned above and given the urgency of the issue, we have set the following goals of this research:

1. to study the theoretical position of the speech therapy support provided to stutterers and their families;

2. to raise the issues in the domestic (Armenian) speech therapy from the point of view of the examined problem.

\section{METHODOLOGY}

Within the frame of this qualitative study as the main method of research the review and analysis of professional, scientific-pedagogical literature and researcher's own experience was selected. In this qualitative research, the researcher is considered to be the most important research tool. Here the researcher uses her experience to get as close to the research phenomenon as possible, which makes it a very demanding technique. On the one hand, the technique requires discipline, analytic reflectivity and methodological experience. On the other hand, a researcher must be open-minded, she must observe herself well, note all the situations, thoughts and actions 
that happen to her during her practice (Byczkowska-Owczarek, 2014). Consideration of prior, relevant literature is essential for all research disciplines. When reading an article, independent of discipline, the author begins by describing previous research to map and assess the research area to motivate the aim of the study and justify the research question and hypotheses. This is generally referred to as the "literature review," "theoretical framework," or "research background" (Snyder, 2019 p.334). Based on the purpose of the review, the researcher used a number of strategies, standards, and guidelines developed especially for conducting a literature review within the frame of current study related to main issues of speech therapy while overcoming problems connected with stuttering.

The following tasks were posed to the researcher based on the main purpose of the research work:

1. to study the statement of work with stuttering person in speech therapy, psychological and pedagogical literature;

2. to make comparative analyzes between the approaches, means, methods and methodologies proposed for overcoming stuttering;

3. to study the position of speech therapy support for families of stutterers in both global and domestic speech therapy;

4. to analyze the speech therapy programs of stutterers from the point of view of the subject under study;

5. to study the experience of advanced speech therapists in terms of work with families of stutterers from theoretical point of view and identify the challenges and difficulties which influence speech therapy intervention process;

6. to identify and theoretically substantiate the need to introduce psychopedagogical and speech therapy conditions for speech therapy pedagogical support in families of stutterers;

7. to analyze the statements that create the practical need for family support for stutterers.

\section{PROCEDURE AND RESULTS}

In order to explain the theoretical implications of speech therapy intervention and support, we have particularly highlighted issues related to the application of methods used to overcome stuttering in the family environment and the difficult task of assisting the family in these matters. The data of the conceptual analysis of the problem show that there are many methods and 
methodologies aimed at regulating the speech of stutterers (Abramova \& Gorkova, 2016; Hovhannisyan, 2001; Harutyunyan, 1993; Missulovin, 1988). At the same time research has proven that family based speech therapy intervention with stutters is organized with great enthusiasm and fervor.

Scientific analysis of the research problem has shown that many authors value the role of functional training with stutterers. The latter allows the appropriate verbal behavior to be formed and use of word as communication mean in different social environment (Anderson \& Ofoe, 2019; Missulovin, 1988). According to authors these interventions must first be organized at home, but in many cases families are not aware about the methods and tools that can be used while organizing this intervention in practice. Krapivina (2003) presents a rather rich methodological consultation for pre-preschoolers in regards of organization and structuring speech therapy intervention. But still clear speech therapy approaches are not available here and author doesn't reflect those (Belyakova \& Dyakova, 2003). Theoretical data analysis shows that they are intended for speech therapists, not families. It should be noted that in speech therapy literature there are also many programs developed for children with speech disorders of pre-school compensatory groups. Mostly these programs are developed for children with phonological problems, those with general underdevelopment of speech, stuttering children and those with mother tongue mastery difficulties. However, in our opinion, all this programs can be considered as tools to support the organization and intervention of overcoming stuttering. Though, it is fair to say that they lack clearly developed work plans, intervention strategies, relevant methodological literature and technologies related to family centered speech therapy (Filicheva, Chirkina, Tumanova, Mironova \& Lagutina, 2008). The authors cover the content of speech disorders and speech therapy intervention peculiarities in details including intervention conducted with stuttering children. They emphasize the content of the general and verbal behavior regulation of stuttering preschoolers. They believe that children should be able to control their behavior, control their emotional reactions and express adequate emotions (learn to keep calm in their new environment, listen carefully to the speaker; do not interrupt adults and friends, etc.). Within the framework of this program, the authors consider the creation of an appropriate social environment as a precondition for correcting stuttering. At the same time, it first of all understands the issues of parent-parent, child-parent relationship, the need to regulate the attitude towards the child's problem, the need for early intervention and overcoming 
of stuttering, the need to meet the general requirements of kindergarten and family (Filicheva, Chirkina, Tumanova, Mironova \& Lagutina, 2008).

The study of the position of speech therapy intervention with the family showed that the main types of work with parents are parent meetings, individual and group counseling conversations (once a month, on the initiative of a speech therapist), open speech therapy classes provided to parents (once a week from the second academic year), parents' corners, which reflect the children's verbal cues, speech therapy tips and instructions.

At the same time, theoretical analysis of review literature shows that the systematic and generalized speech therapy guidelines developed for the purpose of resolving these issues, which should be given to other professionals working with children and all other family members, are almost non-existent. Rau (1964) finds that stuttering needs to be corrected when the first signs of speech disorder appear. According to him, the stuttering of children at the age of 2-5 is easier to overcome than at the age of 5-7. Still, speech therapy experience shows that very often the family, unfortunately, strengthens rather than prevents the first signs. The reason for this is that very often the family tries to help the child "with their own methods", but they are not useful at all or vice versa, not realizing that the child has a serious problem, considering it another childish evil, they force the child "so not to do it", and sometimes, overprotecting the child too much, they abuse his words, etc (Saratikyan, 2014; 2008).

Rau (1964) highlighting the role of the adult and the family in overcoming stubbornness suggests exemplary exercises for speech therapy intervention. These exercises according to our point of view, despite the fact that are quite old, can serve as a basis for developing a family support manual. It is known that Harutyunyan (1993) within the framework of the method of stable regulation of speech of stutterers prioritizes the need for the participation of the whole family and find it very important and crucial. And the methodology developed by her contains many instructions for families. However, it is not possible to consider it as a complete tool of speech therapy support provided to the family, because it requires very professional knowledge in terms of its applicability. We think that it is necessary to separate from these "similar methodologies" and develop such a methodological toolkit for the support of family speech therapy intervention and support that any family will be able to use. In our opinion, the development of such a methodological toolkit is necessary for the support of speech therapy for families of stutterers. 
Based on the above mentioned, we can say that there are few scientific and methodological papers in the explored literature, which are dedicated to support and consultation to families of stutterers in speech therapy.

Still, based on personal experience in speech therapy intervention corrective action to regulate verbal behavior is also very important and requires individual approach to families of stutterers. In order to prevent stuttering, the works with parents and families, in which specialist clarifies the reasons for stuttering, the creation of a psycho-pedagogical environment necessary for overcoming the latter, the prevention of a number of wrong approaches by parents, and the therapeutic approach to regulating the child's verbal behavior seems to be significant.

According to Western experts, the matter of regulating verbal behavior should also be emphasized in the issues of correcting and overcoming stuttering. By the way, one of the main reasons for speech disorder is the peculiarities of family upbringing. Maniadaki (2017) makes an interesting argument - stuttering therapists often try to help stuttering persons. But this view is categorically rejected by Harutyunyan (1993), confirming that it is impossible to cure and get treatment by stuttering. In fact, during all the healing ceremonies, she pays special attention to the words of the family members and insists that they should be treated, because the stuttering family member is "a bad memory ring for the healer" (Andronova, 1986).

The analysis of the behavior and empathy characteristics of the relatives towards the speech of the stuttering children showed that the manifestation of alarming behavior often occupies a big room in their empathy: before the child's speech, "the parent stutters with his whole attitude"; "I'm tense instead of him”, "When he can't say, I'm staring”, "I'm holding my breath until he says something”, those are quotes we often hear from parents. Such behavior pushes the child to stutter in a reflective way, or in other words, reminds him of the stuttering (Saratikyan, 2014; 2009; Andronova, 1986).

As for the Armenian speech therapy literature, there is almost no work on stuttering issues. Author of this paper addressed the issue of stuttering in several of her articles (Saratikyan, 2014; 2009). In the theoretical analysis of the Western experience of speech therapy, many researchers believe that stuttering is more than a disorder of speech rate, rhythm and smoothness.

(Riper, 1982). It should be noted that in the context of the International Classification of Functions developed by the World Health Organization, clear explanations are given on how environmental factors, such as support and relationships, affect the quality of life of stutterers (Yaruss \& Quesal, 
2004).By the way, experience shows that the environment from which the first negative manifestations are received by the stutterer is often the family environment (Daniels \& Gabel, 2004;Riper, 1982). Yairi (1997) conducted research to show how the family environment affects the person who stutters. Results of the study indicate that the role of the family environment has always been important and thus at the center of interest in many studies (Huges, Gabel, Goberman \& Huges, 2011).

\section{DISCUSSION}

Based on our long-term experience working with stutterers, we have presented theoretical and practical analyses of the situation in several articles where we have been reflecting mostly number of issues related to stuttering counseling, early stuttering prevention, correction and overcoming. We are saddened by the fact that the reason for the deepening of stuttering may be professional error or incomplete consultation. According to research, and personal experience parents often say that professionals calm down unnecessarily and advise not to worry, assuring that stuttering is overcome automatically during life span. Some say that the speech therapist advised to speak slowly (but did not substantiate or explain why or how to do it), repeat exercises, ready-made texts, which did not help to overcome the problem, on the contrary, they bored and discouraged the child, etc. (Saratikyan, 2009).

Parents sometimes expect the squeaks to be overcome without any outside intervention, as many have heard that it is improved throughout life, and others do so for fear of deepening stuttering. From conversations with parents, it became clear that the vast majority of parents try to help the child with their own methods. During the research, there were families where they think that the child, if he wants, "can do it" in such a way that he does not stutter. Such approaches show that parents are not aware of the child's psychological difficulties, which is due to the ignorance of the psychological mechanisms of stuttering (Saratikyan, 2014).

A study of the family upbringing of the stuttering children, which shows that mistakes are made in order to help a child, often requires the family to repeat the word or phrase, to breathe, then to speak, to rest, to speak, etc., while such approaches have not been proven as they stifle the child. Attention concentration of self-speech exacerbates a child's neuroticism and negatively affects his or her speech process (expressive speech) (Anderson \& Ofoe, 2019; Saratikyan, 2014; 
2008; Andronova, 1986). There are more demanding parents who punish a child for stuttering, and some promise to reward.

During the literature review, we also encountered educational approaches when the child was compared to his well-spoken sister, brother, neighbor or other person, forcing him to copy his/her the words and speak like them. As it is known, such "support" is also not an effective way, as in that case the cramps often lead to a stable pathological condition and cause serious psychological problems (Andronova, 1986).

Thus, theoretical analyzes conducted based on literature review and personal experience investigation show that many of the works in the professional literature do not offer a solid speech therapy intervention methodological system in terms of practical support for the organization of family centered speech therapy intervention with stuttering children.

In the last twenty years, unlike in the Soviet era, families of people with speech disorders have been more likely to turn to speech therapists. This is due to the fact that along with the development of the profession, the information about the development of speech, its disorders and overcoming prospects, and the provision of visible results have increased among the public(Abramova \& Gorkova, 2016). At the same time, it should be noted that according to the data of health care providers providing speech therapy services, stutterers and their families have started to apply to speech therapists less in recent years, which is explained by the poverty of $40 \%$ of the population and unfavorable social conditions (Missulovin, 2012 p.78). From this perspective we believe that this phenomenon is not only related to the socio-economic conditions of the population, but also to the quality of speech therapy services, the incompatibility of the expected and the obtained results. Speech therapy experience shows that experts, unfortunately, do not have enough knowledge to treat stuttering, working with a stuttering person and their family, that is why they often make the wrong indication, and sometimes, without rejecting the family, work, but the support provided is full of mistakes, shortcomings, and occasionally even completely inappropriate. In addition, speech therapists often avoid correcting this particular speech disorder due to lack of basic conditions needed for their work. For example, more than one specialist works in a speech therapist's room at the same time, the room is in a noisy place, the time is not enough, and so on. As for families, they often have incorrect information about the methods and means of stuttering treatment, as well as about the limits of coping, or after numerous therapeutic attempts have completely lost faith or simply are not aware of many issues related to this problem. 


\section{CONCLUSION}

Thus, summing up the results of the present issues of stuttering overcoming theoretical analysis, we would like to highlight a number of key issues that, in our opinion are current problems in stuttering reduction and mostly refer to the families' full inclusion in speech therapy intervention and use of speech therapy methods in social life. For this reason, we find important the strategies related to:

- developement of speech therapy effective methods, methodics and techniques,

- developement of approaches for using abovementioned methods and techniques in social environment,

- rethink the necessary psychological, pedagogical and speech therapy approaches for the full involvement of families in the process of intervention,

- organization of structured speech therapy support, monitoring of the process, mobilization of technical means required for permanent cooperation in families, stimulation of the demand for families to use them, and training of methods.

We believe that the scientific research based facts presented in this study will act as a serious impetus for giving more in-depth solutions to the issue of speech therapy support for stutterers and will open a place for more researches in the field.

\section{REFERENCE LIST}

1. Abramova, I., V., \& Gorkova, K., A. (2016). Logopedicheskoe soprovojdenie detey s ogranichennimi vozmojnostyami zdorovya $\mathrm{v}$ usloviyakh inklyuzivnoy praktiki// Sovremennie naukoyemkie tekhnologii № 5-2. -s. 301-305.

2. Andronova, L. Z. (1986). Kak lechit zaikanie, M. 1986 s. 159.

3. Anderson, J., D., \& Ofoe, L., C. (2019). The Role of Executive Function in Developmental Stuttering, Semin Speech Lang. 2019 Aug; 40(4): 305-319.Published online 2019 Jul 16. doi: $10.1055 / \mathrm{s}-0039-1692965$

4. Byczkowska-Owczarek, D. (2014). Researcher's personal experiences as a method of embodiment research, Hexis. Theory, Society \& Culture 1(1)

5. Daniels, D., E., \& Gabel, R., M. (2004). The impact of stuttering on identity construction. Topics in Language Disorders, 24 (3), 200-215. 
6. Drapkin, B., Z. (2001). Psikhoterapiya v kompleksnom lechenii zaikaniya u podrostkov. Khrestomatiya. Logopediya. Zaikanie. - M.: V. Sekachev izdatelstvo EKSMO-Press, s. 373-380.

7. Harutyunyna L., Z. (1993). Kak lechit zaikanie, M., 1993 s. 39-55

8. Hovhannisyan, E., V. (2001). Differencirovannaya metodika logopedicheskoy ritmiki dlya zanyatiy s zaikayushimisya podrostkami i vzroslimi, s. 297-308. Khrestomatiya. Logopediya. Zaikanie. - M.: V. Selachev, Izdatelstvo EKSMO- Press-416 s.

9. Huges, Ch., Gabel, R., Goberman, A., \& Huges, S. (2011). Family experiences of people who stutter. Canadian Journal of Speech-Language Pathology and Audiology-Vol. 35, No 1, p. 45-55.

10. Karpovan, L. (2003). Osnovi lichnostno-napravlennoy logopsikhoterapii: uchebnoe posobie 2-e izdanie isprav. i dop., M., 2003. $200 \mathrm{~s}$.

11. Khrestomatiya. Logopediya, Zaikanie. Sost. L. I. Belyakova, E. A. Dyakova - M.: V. Sekachev, Izd-vo EKSMO-Press, 2001, s. 396-408.

12. Krapivina, L., M. (2003). Metodicheskie rekomendacii po organizacii i soderjaniyu logopedicheskikh zanyatiy s zaikayushimisya preddoshkolnogo vozrasta /L. M. Krapivina. - Moskva// Logopediya. Zaikanie: khrestomatia: uchebnoe posobie dlya studentov defektologicheskikh fakultetov visshikh uchebnikh zavedeniy / Sost. L. I. Belyakova, E. A. Dyakova - Moskva; Akademiya, 2003. -s. 163-172.

13. Lokhov, M. I., Fesenko, \& Yu. A. (2000). Zaikanie i logonevroz. Diagnostika i lechenie SPb.: SOTIS, -288 s. 7.

14. Maniadaki, K. (2017). Let's talk about stuttering in a journal of child psychology. Child Psychol. 1(1): 1-2.

15. Missulovin, L., Ya. (2012). Aktualnie problem issledovaniya i preodaleniya zaikaniya u podrostkov i vzroslikh // Vestnik Leningradskoho gosudarstvennogo universiteta, str. 7278.

16. Missulovin, L., Ya. (1988). Lecheniye zaikaniya, L., s. 143-145.

17. Nekrasova, Yu., B. (2001) Aktivnaya logopsikhoterapiya pri vosstanovlenii rechi vzroslikh zaikayushikhsya v ambulatornikh usloviyakh. Khrestomatiya, Zaikanie - M, 2001 s. 380386. 
18. Paylozyan, Zh. H. (2010) Afazia unecogh andzanc khosqi verakangnman metodakan ughecuyc: - Yerevan, 2010, 40 ej.

19. Paylozyan, Zh. H. (2017) Khosqayin haghordakcman verakangnumy afaziayi zhamanak I/ZhG. 00.01.-Mankavarjutjan tesutyun ev praktika (hatuk mankavarjutyun) masnagitutyamb mankavarjakan gitutyunneri doktori gitakan astijani haycman atenakhosutyan seghmagir, Yerevan 2017, 38 ej.

20. Programmi doshkolnikh obrazovatelnikh uchrejdeniy kompensiruyushego vida dlya detey s narusheniyami rechi. Korrekciya narusheniy rechi. T. B. Filicheva, G. V. Chirkina, T. V. Tumanova, S. A. Mironova, A. V. Lagutina // Avtor - sostavitel sbornika G. V. Chirkina. Moskva, Prosvesheniye, 2008.

21. Rau, E., F. (1964) O zaikanii detey doshkolnogo vozrasta. M., s. 8-15.

22. Riper, C. (1982). The nature of stuttering (2nd ed.). Englewood. Cliffs, NJ: Prentice Hall.

23. Saratikyan, L., H. (2014). Kakazoghneri khosqi shtkman ev haghordakcman hmtutyunneri zargacman ughinery, Banber: Mankavarjutyun ev hasarakakan gitutyunner 2 (31): Lingva hratarakchutyun, Yerevan, 563 ej: ej 341-348.

24. Saratikyan, L., H. (2014). Kakazutyan shtkman npatakov tarvogh hogebanamankavarjakan khorhrdatvutyan arandznahatkutyunnery, Hatuk mankavarjutyun ev hogebanutyun, gitametodakan hodvacneri zhoghovacu, Yerevan, Zangak-97, ej 86-90.

25. Saratikyan, L., H. (2009). Kakazutyan kankhargelman ev shtkoghakan mijamtutyan ughinery, Hogekan aroghjutyan haykakan handes 5(1), ej 33-37

26. Saratikyan, L., H. (2008). Kakazoghneri hogebanamankavarjakan hetazotutyan arandznahatkutyunnery, Hatuk mankavarjutyun ev hogebanutyun, gitametodakan hodvacneri zhoghovacu, Yerevan, Zangak-97, ej 51-58.

27. Semeynaya gruppovaya logopsikhoterapiya: Issledovanie zaikaniya; Koll. Monografiya/ pod red. N. L. Karpovoy - SPb, Nestor-Istoriya, 2011.

28. Snyder, H. (2019). Literature review as a research methodology: An overview and guidelines. Journal of Business Research. 104. 333-339. 10.1016/j.jbusres.2019.07.039.

29. Yairi, E. (1997). Home environment and parent child interactions. In R.F. Curlee, \& G. M. Siegal (Eds.), Nature and Treatment of Stuttering: New directions Allyn \& Bacon, Needham Heights, MA, 2nd ed., pp. 24-48. 
30. Yaruss, J., S., \& Quesal, R., W. (2004). Stuttering and the international classification of functioning, disability, and health (ICF): An update. Journal of Communication Disorders, $42,35-52$. 